University of Nebraska - Lincoln

DigitalCommons@University of Nebraska - Lincoln

\title{
Adaptability of irrigated spring canola oil production to the US High Plains
}

\author{
Alexander D. Pavlista \\ University of Nebraska-Lincoln, apavlista@unl.edu \\ Dipak K. Santra \\ University of Nebraska-Lincoln, dsantra2@unl.edu \\ T. A. Isbell \\ USDA-ARS, Peoria, IL, Terry.Isbell@ars.usda.gov \\ D. D. Baltensperger
}

Texas A\&M University, College Station, dbaltensperger@tamu.edu

Gary W. Hergert

University of Nebraska-Lincoln, ghergert1@unl.edu

See next page for additional authors

Follow this and additional works at: https://digitalcommons.unl.edu/panhandleresext

Part of the Agriculture Commons

Pavlista, Alexander D.; Santra, Dipak K.; Isbell, T. A.; Baltensperger, D. D.; Hergert, Gary W.; Krall, J.;

Mesbach, A.; Johnson, J.; O'Neil, M.; Aiken, R.; and Berrada, A., "Adaptability of irrigated spring canola oil production to the US High Plains" (2011). Panhandle Research and Extension Center. 51.

https://digitalcommons.unl.edu/panhandleresext/51

This Article is brought to you for free and open access by the Agricultural Research Division of IANR at DigitalCommons@University of Nebraska - Lincoln. It has been accepted for inclusion in Panhandle Research and Extension Center by an authorized administrator of DigitalCommons@University of Nebraska - Lincoln. 


\section{Authors}

Alexander D. Pavlista, Dipak K. Santra, T. A. Isbell, D. D. Baltensperger, Gary W. Hergert, J. Krall, A. Mesbach, J. Johnson, M. O'Neil, R. Aiken, and A. Berrada 


\title{
Adaptability of irrigated spring canola oil production to the US High Plains
}

\author{
A.D. Pavlista ${ }^{a}, *$, D.K. Santra ${ }^{a}$, T.A. Isbell ${ }^{b}$, D.D. Baltensperger ${ }^{c}$, G.W. Hergert ${ }^{a}$, J. Krall ${ }^{d}$,

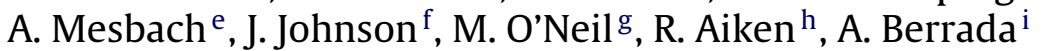 \\ a University of Nebraska, PREC, Scottsbluff, NE 69361, USA \\ b USDA-ARS, Peoria, IL 61604, USA \\ c Texas A\&M University, College Station, TX 77843, USA \\ d University of Wyoming, SAREC, Lingle, WY 82223, USA \\ e University of Wyoming, NAREC, Powell, WY 82435, USA \\ ${ }^{f}$ Colorado State University, Ft. Collins, CO 80523, USA \\ ${ }^{g}$ New Mexico State University, Farmington, NM 87499, USA \\ h Kansas State University, Colby, KS 67701, USA \\ ${ }^{i}$ Colorado State University, Yellow Jacket, CO 81335, USA
}

\section{A R T I C L E I N F O}

\section{Article history:}

Received 22 June 2010

Received in revised form

23 September 2010

Accepted 4 October 2010

\section{Keywords:}

C18:1

C18:2

C18:3

C22:1

Omega-3

Omega-6

Omega-9

Erucic acid

Biofuel

Biodiesel

Great Plains

\begin{abstract}
A B S T R A C T
Canola oil is high in oleic acid which is commonly used for food and industrial purposes. To determine adaptability of spring canola (Brassica napus L.) to the High Plains for industrial oil production, 26 irrigated trials were conducted from 2005 to 2008 . Trials were divided into five regions $-1: 36-37^{\circ} \mathrm{N}$ $108^{\circ} \mathrm{W} ; 2: 39-40^{\circ} \mathrm{N} 101-103^{\circ} \mathrm{W} ; 3: 41-42^{\circ} \mathrm{N} 102-103^{\circ} \mathrm{W} ; 4: 41-42^{\circ} \mathrm{N} 104^{\circ} \mathrm{W} ; 5: 43-44^{\circ} \mathrm{N} 106-108^{\circ} \mathrm{W}$. Cultural practices were based on site-specific protocols. Four cultivars, Hyola 401, Hyola 357 Magnum, SW Marksman, and SW Patriot, were planted in replicated plots in April or May under standard irrigation and harvested in July to October depending on region. Seed yield Hyola 401 and Hyola 357 Magnum were higher than SW Marksman and SW Patriot across the five regions and within Regions 1, 2, 3, and 5. Regions 1, 2 and 3 yielded significantly greater than did Regions 4 and 5. Samples from 18 trials were examined for their oil content and fatty acid distribution. The four cultivars had greater than $38 \%$ oil content; SW Marksman and SW Patriot had higher oil content than Hyola 401 and Hyola 357 Mag. Higher oil content was achieved in Regions 1, 4 and 5. Across and within regions, the percent of oleic acid did not differ for the four cultivars. The mean content of oleic acid decreased going north from Region 2 to Region 5 , as did seed yield in the High Plains. Linoleic acid increased going north from Region 1 . Linolenic acids showed little variation across regions. Considering yield and total oil content together, growing spring canola would be excellent in the High Plains.
\end{abstract}

(c) 2010 Elsevier B.V. All rights reserved.

\section{Introduction}

Dryland cropping systems in the US High Plains have moved from winter wheat-fallow to more intensive systems that include warmer season crops. Adaptation of spring-planted, cool-season broadleaf crops with market opportunities would significantly benefit rotations for producers. Spring canola, a special type of rapeseed (Brassica napus L.), could fit into these crop rotations.

Canola originated in Canada through genetic modification of rapeseed by conventional plant breeding (Shahidi, 1990). It emerged in the 1970s as a viable oilseed, able to transform oil and meal from unacceptable to valuable products for both human and animal consumption. Since the 1970s, canola has been accepted by

\footnotetext{
* Corresponding author. Tel.: +1 308632 1240; fax: +1 3086321365 .

E-mail address: apavlista@unl.edu (A.D. Pavlista).
}

consumers for its unique fatty acid profile. Nutritionists consider canola's fatty acid profile to be the most desirable of all available vegetable oil. Furthermore, canola has less than $30 \mu \mathrm{g}$ of glucosinolates per gram of oil-free meal and its seed meal can be used as a high-quality protein supplement for livestock (Bhardwaj, 2007).

Canola having over $40 \%$ oil content is one of the highest oilcontaining crops in the world. Canola has a high oleic acid content $(\sim 65 \%)$ and low amount of saturates ( $\sim 6 \%)$ which makes this oil desirable for a variety of food (Sakurai and Pokorny, 2003; BeareRogers, 2002) and industrial applications (Dyer et al., 2008). High oleic acid varieties of canola will be even more suitable for a wide variety of fuels and lubricants because of the increased oxidative stability of a highly mono-unsaturated oil. The low saturate content of canola oil imparts good cold temperature properties particularly, which makes canola oil desirable as a base stock for biodiesel. In addition, these properties are carried through a cranking process to make green diesel where thermally cracked canola demonstrated 
superior cold temperatures properties in the resultant fuel when compared to soybean oil (Luo et al., 2010).

Growing environments have been reported to impact seed yield and oil quantity as well as quality. In order to make canola a profitable crop in the High Plains, it is important to know how different regions within the High Plains impact seed yield, oil content and fatty acid profile.

\section{Materials and methods}

\subsection{Field trials}

From 2005 to 2008, 26 field trials were conducted across the High Plains from northern New Mexico to northern Wyoming (Fig. 1). Sites were divided into five regions based on their map coordinates-1: $36-37^{\circ} \mathrm{N} 108^{\circ} \mathrm{W} ; 2$ : $39-40^{\circ} \mathrm{N} 101-103^{\circ} \mathrm{W} ; 3$ : $41-42^{\circ} \mathrm{N} 102-103^{\circ} \mathrm{W} ; 4: 41-42^{\circ} \mathrm{N} 104^{\circ} \mathrm{W} ; 5: 43-44^{\circ} \mathrm{N} 106-108^{\circ} \mathrm{W}$ (Table 1). Trials were planted from early April to early June. The spring canola (B. napus L.) cultivars tested in these sites were Hyola 401, Hyola 357 Magnum, SW Marksman, and SW Patriot. Seed planted at all locations each year were from the same seed lot donated by Interstate Seed Co. Trials were designed as RCB with four replicated plots. Plots were four rows spaced $0.3 \mathrm{~m}$ apart and 3-6 $\mathrm{m}$ long. Seeding rate was $7-9 \mathrm{~kg} / \mathrm{ha}$. The most common previous crop was winter wheat while in a few trials, canola followed oat, corn, dry bean, or alfalfa. All trials were irrigated under an overhead irrigation system (center-pivot or linear-move). The amount depended on rainfall and was targeted to that used for growing irrigated wheat. Total precipitation from planting to harvest ranged from 25 to $60 \mathrm{~cm}$ with higher amounts applied Yellow Jacket, CO, and Farmington, NM. Cultural practices were site-specific. Fer-
Table 1

Coordinates and years for each site.

\begin{tabular}{llll}
\hline Region & Site & Coordinates & Trial years \\
\hline 1. Southwest & Farmington NM & $36^{\circ} 45^{\prime} \mathrm{N} 108^{\circ} 10^{\prime} \mathrm{W}$ & $2006 \mathrm{c} 2008 \mathrm{a}$ \\
& Yellow Jacket CO & $37^{\circ} 53^{\prime} \mathrm{N} 108^{\circ} 73^{\prime} \mathrm{W}$ & $2006 \mathrm{c} 2008 \mathrm{c}$ \\
2. East & Colby KS & $3^{\circ} 22^{\prime} \mathrm{N} 101^{\circ} 04^{\prime} \mathrm{W}$ & $2005 \mathrm{c} 2006 \mathrm{~b}$ \\
& Akron CO & $40^{\circ} 09^{\prime} \mathrm{N} 103^{\circ} 08^{\prime} \mathrm{W}$ & $2006 \mathrm{c} 2007 \mathrm{a}^{*}$ \\
3. Central & Sidney NE & $41^{\circ} 13^{\prime} \mathrm{N} 103^{\circ} 00^{\prime} \mathrm{W}$ & $2005 \mathrm{c} 2006 \mathrm{c}$ \\
& Scottsbluff NE & $41^{\circ} 50^{\prime} \mathrm{N} 103^{\circ} 41^{\prime} \mathrm{W}$ & $2005 \mathrm{c} 2006 \mathrm{c}$ \\
& & & $2007 \mathrm{a} 2008 \mathrm{c}$ \\
& Alliance NE & $42^{\circ} 08^{\prime} \mathrm{N} 102^{\circ} 51^{\prime} \mathrm{W}$ & $2005 \mathrm{c}$ \\
& 4. West & $41^{\circ} 25^{\prime} \mathrm{N} 104^{\circ} 06^{\prime} \mathrm{W}$ & $2005 \mathrm{~b} 2006 \mathrm{c}$ \\
& LaGrange WY & $41^{\circ} 38^{\prime} \mathrm{N} 104^{\circ} 09^{\prime} \mathrm{W}$ & $2008 \mathrm{a}$ \\
& Lingle WY & $42^{\circ} 08^{\prime} \mathrm{N} 104^{\circ} 20^{\prime} \mathrm{W}$ & $2007 \mathrm{a}$ \\
& Torrington WY & $42^{\circ} 20^{\prime} \mathrm{N} 104^{\circ} 11^{\prime} \mathrm{W}$ & $2006 \mathrm{c}$ \\
& Powell WY & $44^{\circ} 45^{\prime} \mathrm{N} 108^{\circ} 45^{\prime} \mathrm{W}$ & $2005 \mathrm{c} 2006 \mathrm{c}$ \\
& & & $2007 \mathrm{a} 2008 \mathrm{c}$ \\
& Sheridan WY & $44^{\circ} 38^{\prime} \mathrm{N} 106^{\circ} 57^{\prime} \mathrm{W}$ & $2006 \mathrm{a}$
\end{tabular}

*: two trials; a: trials in yield studies; b: trials in oil analyses; c: trials used for both yield determination and oil analyses.

tilization ranged from 45 to $168 \mathrm{~kg} \mathrm{~N} /$ ha. In some sites, $\mathrm{N}$ was supplemented with $25-35 \mathrm{~kg} \mathrm{~S} / \mathrm{ha}$ and $20-50 \mathrm{~kg}$ P/ha. In NM, $60 \mathrm{~kg}$ K/ha was also added. Since Hyola 401, unlike Hyola 357 Magnum, SW Marksman and SW Patriot, is not resistant to glyphosate, weed control in trials was accomplished using either trifluralin or ethalfluralin. Insect control depended on local pressure and materials used were esfenvalerate, imidacloprid, or z-cypermethrin. No fungicides were applied. Trials were harvested in July and August at all sites in WY and NE, and in Akron, CO, and Colby, KS, but in September or October in Yellow Jacket, CO, and Farmington, NM.

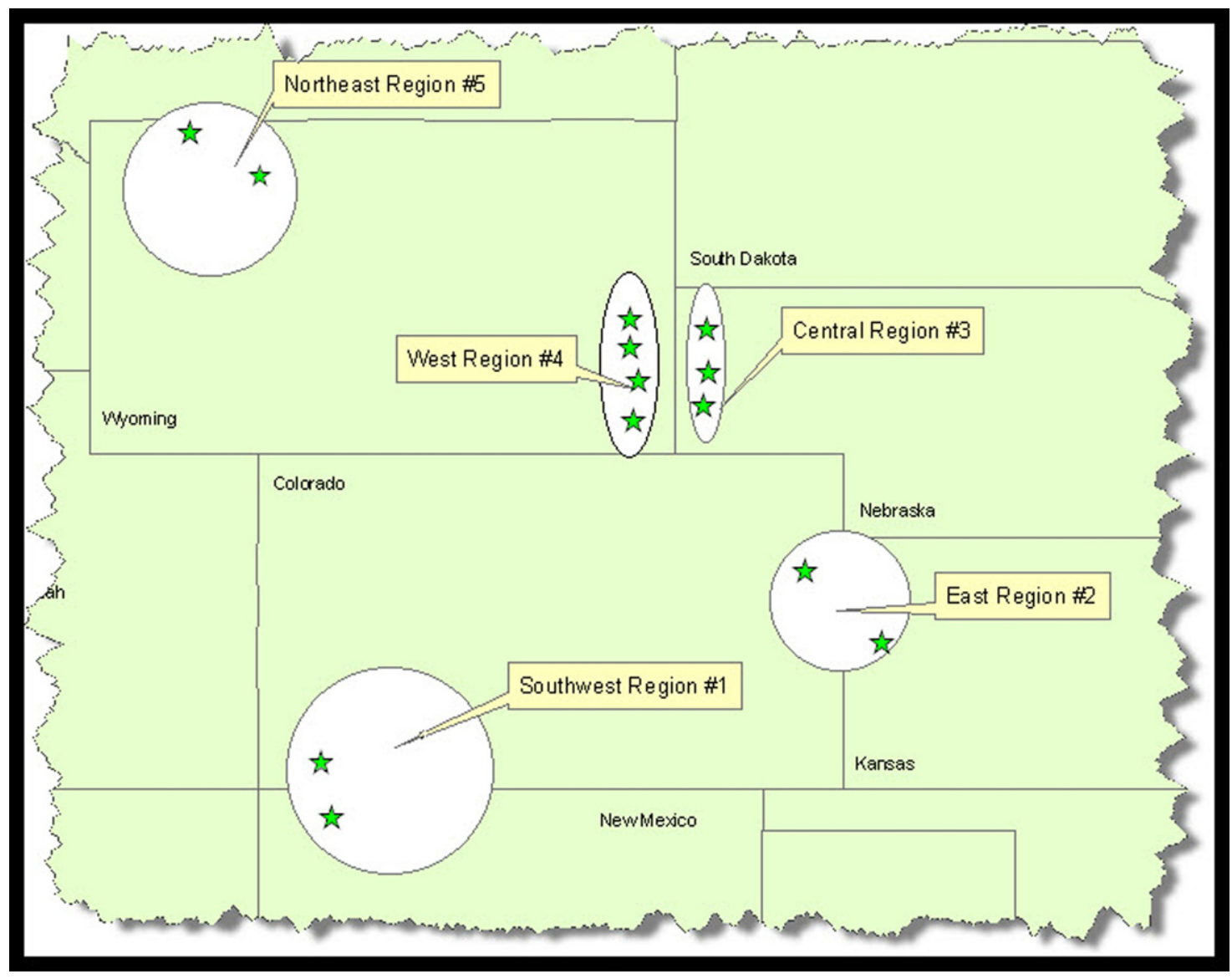

Fig. 1. Map showing geographical location of spring canola trials. 


\subsection{Cultivars}

Hyola 401, Hyola 357 Magnum, SW Patriot, and SW Marksman were donated by Interstate Seed Company in West Fargo, ND. Hyola 401 is a conventional hybrid (Porter and LaGare, 2006), and Hyola 357 Magnum is genetic modification of Hyola 401 for glyphosate (Roundup) resistance. It is widely adaptable to many growing regions (Anon., 2010). Both these varieties were developed by Adavanta Seed, Winnipeg, MB (Porter and LaGare, 2006). SW Marksman, a synthetic variety, and SW Patriot, a hybrid, were developed by Svalof Weibull Ltd., Saskatoon, SK (Porter and LaGare, 2006). Hyola 401 and Hyola 357 Magnum are earlier in flowering and seed maturity than SW Patriot and SW Marksman. Hyola cultivars are shorter in height compared to SW varieties. Except for Hyola 401, the other cultivars are resistant to glyphosate (Ronudup Ready types).

\subsection{Statistics}

Significant difference for all data between regions and cultivars were determined using Proc GLM (SAS Inst, 2003). Means between regions were separated using Duncan's Multiple Range and means between cultivars were separated by least significant difference.

\subsection{Fatty acid determination}

Fatty acid analysis was conducted on a Hewlett Packard (Palo Alta, CA) 5890 Series II gas chromatograph (GC) equipped with a flame-ionization detector and a 7963 autosampler/injector. GC separations were obtained on a SP-2380 $30 \mathrm{~m} \times 0.25 \mathrm{~mm}$ i.d. poly $(90 \%$ biscyanopropyl/10\% cyanopropylphenyl siloxane) capillary column from Supelco (Bellefonte, PA). GC conditions were: programmed temperature ramp from $180^{\circ} \mathrm{C}$ to $210^{\circ} \mathrm{C}$ at $7^{\circ} \mathrm{C} / \mathrm{min}$ then temperature ramped at $30^{\circ} \mathrm{C} / \mathrm{min}$ to $265^{\circ} \mathrm{C}$ and hold at $265^{\circ} \mathrm{C}$ for $3 \mathrm{~min}$. The injector temperature was set at $265^{\circ} \mathrm{C}$ and flame ionization detector was heated to $250^{\circ} \mathrm{C}$ with a helium flow rate through the column of $1 \mathrm{ml} / \mathrm{min}$, split ratio of 100:1 and a septum purge of $4 \mathrm{ml} / \mathrm{min}$. A standard mix of C8 to C30 saturated fatty acid methyl esters GLC mixture supplied by Nu-Check Prep (Elysian, MN) was used to identify retention times of fatty ester components in the seed oil samples.

Fatty acid methyl esters were synthesized by placing 50 seeds in a $20 \mathrm{ml}$ scintillation vial containing $5 \mathrm{ml}$ of $0.25 \mathrm{M}$ sodium methoxide solution then grinding with a homogenizer from Cole-Parmer (Vernon Hills, IL) for $1 \mathrm{~min}$ or until no whole seeds were present. The vial was sealed with an aluminum lined screw cap and the vial placed in an aluminum heating block maintained at $60^{\circ} \mathrm{C}$ for $30 \mathrm{~min}$. After this time the vials were removed and $7 \mathrm{ml}$ of hexane and $7 \mathrm{ml}$ of saturated sodium chloride solution were added to the vial. The contents of the vial were mixed thoroughly and then the layers were allowed to separate. A $2 \mathrm{ml}$ aliquot from the top hexane layer was removed and placed in a $2 \mathrm{ml} \mathrm{GC}$ target vial and sealed with a crimp cap. The vial was placed in the GC autosampler and injected onto the capillary column for analysis under the conditions described above.

Pulsed Nuclear Magnetic Resonance (pNMR) for total oil content was determined on a Bruker (Billerica, MA) mq-CU 20-series, Firmware v 2.50Rev.00 using factory instrument setting 909_18A, NMR frequency $19.98 \mathrm{MHz}$ at $40^{\circ} \mathrm{C}$. pNMR instrument settings: digital bandwidth $20,000 \mathrm{kHz}$; gain $63 \mathrm{~dB} ; 16$ scans with 2 s recycle delay; pulse separation $3.5 \mathrm{~ms}$ with sampling window of 6.9583-7.0583 ms. Seed samples were weighed to the tenth milligram and placed into a Pyrex No. 9820 vial and then heated to $40^{\circ} \mathrm{C}$ for $2 \mathrm{~h}$ before analysis. Response factors for each sample were measured and reported to the tenth milligram of oil. Standard curves for pNMR were developed by solvent extraction of bulk canola seed samples representing a mixed sample from all the cultivars studied. Solvent extracted oil content was determined by isolated mass balance obtained by double extraction of canola seed using a Foss 1043 Extraction Unit (Eden Prairie, MN). The bulk seed sample was thoroughly ground in a coffee mill then $0.5000 \mathrm{~g}$ of ground sample was placed into a folded weigh paper and transferred to an extraction unit. Circulation of hot petroleum ether was maintained for $1 \mathrm{~h}$ through the sample as it was soaked in the solvent. The sample was then rinsed for $40 \mathrm{~min}$ with the evaporated petroleum ether. The extract was concentrated by distillation over $30 \mathrm{~min}$ to remove the extraction solvent. The mark was then subjected to the same extraction process a second time with fresh solvent. Oil from both extractions was combined and then dried at $80^{\circ} \mathrm{C}$ under vacuum for $2 \mathrm{~h}$ before the final oil extracted mass balance was determined. After the oil content of the bulk seed was determined by extraction, a calibration curve using whole seed was constructed. Data points for the curve were generated by massing incremental amounts of bulk seed $(0.450 \mathrm{~g}$ up to $1.500 \mathrm{~g})$ into a tared Pyrex No. 9820 vial and the response values of each individual point determined by pNMR as described above. This method resulted in a standard curve with a correlation constant of 0.9997 and covered an oil mass range sufficient to span all of the oil contents in the seed of the cultivars analyzed.

\section{Results}

\subsection{Seed yield}

There was no significant interaction between region and entry for spring canola seed yield. Yields from Regions 1, 2 and 3 were not significantly different $(p<0.05)$ from each other but were different from that in Region 5 (Table 1). Yield from Region 1 was also significantly higher than from Region 4 . The linear regression of regional yield means was expressed in Eq. (1) which indicated an expected $249 \mathrm{~kg} / \mathrm{ha}$ decrease as regional location was further north in the High Plains. Regional differences were primarily due to yield differences of Hyola 401 and Hyola 357 Magnum. These cultivars yielded significantly greater than SW Marksman and SW Patriot except in Region 4 where there was no significant difference between cultivars (Table 2 ).

Yield $(\mathrm{kg} / \mathrm{ha})=-249($ regional code, $1-5)+2310$,

$r^{2}=0.74, \quad p<0.01$.

\subsection{Oil content}

There was no significant interaction between region and entry for oil content. Total oil content expressed as a \% of dry seed weight did not significantly vary within regions for any of the four cultivars (data not shown). However, oil content across regions was significantly different (Table 3 ). There was a significant trend of increasing oil content from Regions 2 to 5. Eq. (2) suggested that there was a $2 \%$ increase in oil content with changes in region moving north and west. This was inverse from the trend in seed yield which was lowest in Regions 4 and 5. When seed yields were combined with oil content, oil production per unit area was greater in Regions 1, 2 and 3 than from Regions 4 and 5 (data not shown). All four cultivars contained greater than $38 \%$ oil by weight. Within regions, Hyola 401 and Hyola 357 Magnum tended to have less total oil than SW Marksman (Table 3).

Oil content $(\%)=2.06($ regional code, $1-5)+31.3$,

$r^{2}=0.99, \quad p<0.01$. 
Table 2

Spring canola seed yields across regions and cultivars, 24 trials.

\begin{tabular}{|c|c|c|c|c|c|c|}
\hline Region $^{\mathrm{a}}$ & Hyola 401 & Hyola 357 Mag. & SW Marksman (kg/ha) & SW Patriot & Regional means & $\begin{array}{l}\text { Cultivar separation } \\
\text { LSD }_{0.05^{\mathrm{b}}}\end{array}$ \\
\hline 1 & $2206 A^{b}$ & $2326 \mathrm{~A}$ & 1769 & 1749 & $2022 \mathrm{~A}$ & 479 \\
\hline 2 & $1929 \mathrm{AB}$ & $1914 \mathrm{AB}$ & 1209 & 1378 & $1607 \mathrm{AB}$ & 300 \\
\hline 3 & $1981 \mathrm{AB}$ & $2124 \mathrm{AB}$ & 1805 & 1675 & $1896 \mathrm{AB}$ & 256 \\
\hline 4 & $1427 \mathrm{AB}$ & $1434 \mathrm{AB}$ & 1614 & 1363 & 1459 B & $n s^{c}$ \\
\hline 5 & $874 \mathrm{~B}$ & 1047 B & 788 & 696 & $851 \mathrm{C}$ & 174 \\
\hline Means & 1687 & 1789 & 1459 & 1382 & & 144 \\
\hline $\mathrm{b}$ & $*$ & $*$ & ns & ns & * & \\
\hline
\end{tabular}

a Region 1: Farmington, NM \& Yellow Jacket, CO, four trials. Region 2: Akron, CO \& Colby, KS, three trials. Region 3: Scottsbluff, Sidney \& Alliance, NE, six trials. Region 4 : Albin, LaGrange, Lingle \& Torrington, WY, four trials. Region 5: Powell \& Sheridan, WY, four trials.

b Regional mean separation by Duncan's Multiple Range at $p<0.05$. Cultivar mean separation by least significant difference.

c ns = not significant.

Table 3

Spring canola oil content across regions and cultivars, 18 trials.

\begin{tabular}{|c|c|c|c|c|}
\hline Region $^{\mathrm{a}}$ & $\begin{array}{l}\text { Oil content } \\
\% \text { dry weight }\end{array}$ & Oleic acid (C18:1 d9) & $\begin{array}{l}\text { Linoleic acid (C18:2) } \\
\% \text { total oil }\end{array}$ & Linoleic acid (C18:3) \\
\hline 1 & $40.3 \mathrm{AB}^{\mathrm{b}}$ & $64.9 \mathrm{BC}$ & $17.6 \mathrm{~B}$ & $9.3 \mathrm{~A}$ \\
\hline 2 & $35.5 \mathrm{C}$ & $66.4 \mathrm{~A}$ & $18.7 \mathrm{~A}$ & $8.0 \mathrm{~B}$ \\
\hline 3 & $37.2 \mathrm{BC}$ & $66.2 \mathrm{AB}$ & $19.2 \mathrm{~A}$ & $8.3 \mathrm{~B}$ \\
\hline 4 & $39.8 \mathrm{AB}$ & $64.7 \mathrm{C}$ & $19.4 \mathrm{~A}$ & $9.5 \mathrm{~A}$ \\
\hline 5 & $41.5 \mathrm{~A}$ & 63.3 D & $19.7 \mathrm{~A}$ & $9.1 \mathrm{~A}$ \\
\hline Cultivar & $\begin{array}{l}\text { Oil content } \\
\text { \% dry weight }\end{array}$ & Oleic acid (C18:1 d9) & $\begin{array}{l}\text { Linoleic acid (C18:2) } \\
\% \text { total oil }\end{array}$ & Linoleic acid (C18:3) \\
\hline Hyola 401 & $38.4 \mathrm{~B}$ & $65.8 \mathrm{AB}$ & $17.9 \mathrm{~B}$ & 8.7 \\
\hline Hyola 357 Mag. & $38.0 \mathrm{~B}$ & $65.9 \mathrm{~A}$ & $18.3 \mathrm{~B}$ & 8.7 \\
\hline SW Marksman & $39.4 \mathrm{~A}$ & $64.8 \mathrm{BC}$ & $19.6 \mathrm{~A}$ & 8.9 \\
\hline SW Patriot & $\begin{array}{l}38.7 \mathrm{AB} \\
*\end{array}$ & $\begin{array}{l}64.5 \mathrm{C} \\
*\end{array}$ & $20.1 \mathrm{~A}$ & 8.8 \\
\hline
\end{tabular}

a Region 1: Farmington, NM \& Yellow Jacket, CO, four trials. Region 2: Akron, CO \& Colby, KS, five trials. Region 3: Scottsbluff, Sidney \& Alliance, NE, seven trials. Region 4: Albin, LaGrange, Lingle \& Torrington, WY, six trials. Region 5: Powell \& Sheridan, WY, five trials.

b Means separated by Duncan's Multiple Range at $p<0.05$.

The major component of oil was oleic acid (C18:1 omega-9) which accounted for over $63 \%$ of the oil (Table 3 ). Oleic acid was higher in seed produced in Regions 2 and 3 compared to Regions 4 and 5 . When combining with seed yield, Regions 4 and 5 would have the lowest oleic acid production per unit area. Comparing cultivars, Hyola 401 and Hyola 357 Magnum had more oleic acid than SW Patriot.

The second major component of oil was linoleic acid (C18:2 omega-6) which ranged from $17.6 \%$ to $20.1 \%$ of total oil (Table 3 ). Seed from Region 1 had significantly lower percent linoleic acid than the other four regions. Combining seed yield with linoleic acid content, Regions 4 and 5 produced less linoleic acid per area. Within regions, Hyola 401 and Hyola 357 Magnum had less linoleic acid in seed than SW Marksman and SW Patriot. Across Regions 2 through 5 as the oleic acid content decreased the linoleic content increased consistent with the trend of a more northerly and cooler climate which tend to produce more unsaturated oils.

Linolenic acid (C18:3), sometimes referred to as 'omega-3' fatty acid, accounted for about $9 \%$ of the total oil. Regions 2 and 3 had the lowest amount of oil compared to Regions 1,4 , and 5 . There was no significant difference observed between cultivars.

No erucic acid (C22:1) was observed in the trials.

\section{Discussion}

There is little open information on Hyola 401, Hyola 357 Magnum, SW Marksman, and SW Patriot in the scientific literature. Hyola 357 Magnum and Hyola 401 were early to average in maturity and shorter in stature across regions. Whereas, SW Marksman and SW Patriot were average to late maturity and taller in stature. Similar results were reported in cultivar evaluation trials conducted in MN, ND, and IA (Bradley et al., 2006; Gibson et al., 2007; Porter and LaGare, 2006). Seed yield of Hyola 357 Magnum was higher than SW Marksman and SW Patriot, but oil content was lower in cultivar evaluation throughout MN. Hyola 357 Magnum and Hyola 401 bloomed two to three days earlier than SW Marksman and SW Patriot (Porter and LaGare, 2006). Similar result was also reported in ND (Anon., 2006) and IA (Gibson et al., 2007). Seed yield and oil content results of the four cultivars were very similar to those reports here.

Planting date has been reported in several studies to be a major factor in spring canola growth, flowering time and yield (Angadi et al., 2004; Chen et al., 2005; Pavlista and Baltensperger, 2007). Across the High Plains of Canada and the USA, seeding from late March to mid-April gave optimal yield. The aim of this study was to have all trials planted to provide maximum yield. All trials in Regions 2, 3 and 4 were planted within that time period. Trials in Regions 1 and 5 were planted in late April and early May except for one trial in 2008 at Yellow Jacket, CO, that was planted on 2 June and gave the lowest yield for Region 1 . The late planting in Region 5 (north Wyoming) may account for this region's significantly lower yield than the other four. In Montana, planting date by mid-April was reported optimal (Chen et al., 2005).

Temperature may explain the differences in seed yield and oil content between regions in the High Plains. Seed germination and early seedling development has been related to temperature (Nykiforuk and Johnson-Flanagan, 1994). As soil temperature may play a role in canola establishment, soil temperature for the first 14 days from planting for each trial was compared to yields. Soil temperature ranged from 7.1 to $14.4^{\circ} \mathrm{C}$. There was no correlation $\left(r^{2}=0.03\right)$ which suggested that regional differences at planting did not account for regional yield differences. A negative corre- 
lation between air temperature at mid to late season and yield was reported by Nuttall et al. (1992). This was further narrowed to the maximum temperature at and around the date of mid-bloom (Angadi et al., 2000). Johnston et al. (2002) proposed that the optimal temperature for flowering was $20^{\circ} \mathrm{C}$ for canola. The maximum temperature at flowering in Regions 1 and 2 were about $30^{\circ} \mathrm{C}$, and for Region 3, it was $24^{\circ} \mathrm{C}$. These regions had the highest yields. However, mean daily temperatures around flowering in all regions were between 16 and $24^{\circ} \mathrm{C}$. Maximum and mean air temperature for the week of flowering were recorded and compared to yield. There was no correlation observed $\left(r^{2}<0.05\right)$. Recently, it was reported that the length of time to bloom was negatively correlated to yield (Chen et al., 2005). Days to flowering was determined by the length of time from planting to flowering and compared to yield. There was no significant correlation observed and a low $r^{2}$ value but a slight tendency that low yields may be obtained with a long time period to bloom as predicted by Chen et al. (2005).

Temperature during seed maturation has an influence on fatty acid composition (Canvin, 1965; Mazliak, 1988; Yaniv et al., 1989). Generally warm, dry growing conditions favor the production of saturated fatty acids, whereas cooler, moist conditions favor polysaturated fatty acids (Harris et al., 1978; Slack and Rughan, 1978; Seiler, 1983). Yaniv et al. (1995) reported higher oleic acid at higher temperature accompanied by decrease in linolenic acid. In this study, oleic acid increased, and polyunsaturated fatty acid (linolenic and linoleic acid) decreased going south from Region 5. This is may be due to higher temperature during lipid biosynthesis. Regions 1, 2, and 3 favored synthesis of more oleic acid and less polyunsaturated fatty acids.

\section{Conclusion}

In general, it appeared that the WY sites had lower yields than sites in NE and further south. There was a trend to higher total oil content as sites were located further north in the High Plains. But, the amount of oleic acid in the oil was greatest in seed from Regions 2 (east CO and west KS) and 3 (NE Panhandle); lower from Region 4 (east WY), and least from Region 5 (northwest WY). Linoleic acid showed little change across regions although Region 1 (southwest $\mathrm{CO}$ and north NM) was the lowest. When combining oil content and seed yield, the lowest oil production was from WY sites, and the highest oil production were from west NE, east CO, west KS, southwest CO, and north NM. Hyola 401 and Hyola 357 Mag. had greater seed yields than SW Marksman and SW Patriot, but generally they produced less total oil per unit area than SW Marksman and SW Patriot. However, Hyola 401 and Hyola 357 Mag. had higher oleic acid content. This study suggested that for a good balance between seed yield and production of oleic acid and linoleic acid, growing spring canola would work well in the Nebraska Panhandle.

\section{References}

Angadi, S.V., Cutforth, H.W., McConkey, B.G., Gan, Y., 2004. Early seeding improves the sustainability of canola and mustard production on the Canadian semiarid prairie. Can. J. Plant Sci. 84, 705-711.
Angadi, S.V., Cutforth, H.W., Miller, P.R., McConkey, B.G., Entz, M.H., Brandt, S.A., Volkmar, K.M., 2000. Response of three Brassica species to high temperature stress during reproductive growth. Can. J. Plant Sci. 80, 693-701.

Anon., 2006. Agro-Tech Public Canola Yield Trials., http://www.agrotechresearch. com.

Anon., 2010. Dekalb brand spring canola 2010 agronomic rating. In: 2010 Seed Resource Guide, pp. 60-61 http://www.asgrowanddekalb.com/web/pdf/ products/2010 seed resource guide north.pdf.

Beare-Rogers, J., 2002. Dietary fatty acids in an era of genetic modification. Inform. $13,632-633$.

Bhardwaj, H.L., 2007. Utilizing locally-produced canola to manufacture biodiesel. In: Janick, J., Whipkey, A. (Eds.), Issues in New Crops and New Uses. ASHS Press, Alexandria, VA, pp. 43-46.

Bradley, C.A., Hensen, R.A., Porter, P.M., LeGare, D.G., del Rio, L.E., Knot, S.D., 2006. Response of canola cultivars to Sclerotinia sclerotiorium in controlled and field environments. Plant Dis. 90, 215-221.

Canvin, D.T., 1965. The effect of temperature on the oil content and fatty acid composition of the oil from several oil seed crops. Can. J. Bot. 43, 63-69.

Chen, C., Jackson, G., Karnes, N., Wichman, D., Johnson, G., Johnson, D., 2005. Determining the feasibility of early seeding canola in the northern Great Plains. Agron. J. 97, 1252-1262.

Dyer, J.M., Stymne, S., Green, A.G., Carlsson, A.S., 2008. High-value oils from plants. Plant J. 54, 640-655.

Gibson, L., Cheema, M., Patrick, G., 2007. Spring Canola Variety Performance in Iowa., http://www.agmrc.org/media/cms/Scanola07.

Harris, H.C., McWilliam, J.R., Masson, W.E., 1978. Influence of temperature on oil content and composition of sunflower seed. Aust. J. Agric. Res. 29, 12031212.

Johnston, A.M., Tanaka, D.L., Miller, P.R., Brandt, S.A., Nielsen, D.C., Lafond, G.F., Riveland, N.R., 2002. Oilseed crops for semiarid cropping systems in the northern Great Plains. Agron. J. 94, 231-240.

Luo, Y., Ahmed, I., Kubatova, A., Stavova, J., Aulich, T., Sadrameli, S., Seames, W.S., 2010. The thermal cracking of soybean/canola oils and their methyl esters. Fuel Process. Technol. 91, 613-617.

Mazliak, P., 1988. Environmental effects on fatty acid quality. In: Pinfield, N.J., Stobart, A.K. (Eds.), Plant Lipids: Target for Manipulation, vol. 17. British Plant Growth Regulator Group, pp. 57-71.

Nuttall, W.F., Moulin, A.P., Townley-Smith, L.J., 1992. Yield response of canola to nitrogen, phosphorus, precipitation, and temperature. Agron. J. 84, 765768.

Nykiforuk, C.L., Johnson-Flanagan, A.M., 1994. Germination and early seedling development under low temperature in canola. Crop Sci. 34, 1047-1054.

Pavlista, A.D., Baltensperger, D.D., 2007. Phenology of oilseed crops for bio-diesel in the high plains. In: Janick, J., Whipkey, A. (Eds.), Issues in New Crops and New Uses. ASHS Press, Alexandria, VA, pp. 60-63.

Porter, P.M., LaGare, D.G., 2006. Canola Variety Trial Results. U Minn Agric Exp Sta, http://www.maes.umn.edu/06VarietalTrials/canola.pdf.

Sakurai, H., Pokorny, J., 2003. The development and application of novel vegetable oils tailor-made for specific human dietary needs. Europ. J. Lipid Sci. Tech. 105, 769-778, doi:10.1002/ejlt.200300890.

SAS Institute, 2003. SAS System for Windows. Release 9.1 ed. SAS Institute Inc., Cary, NC.

Seiler, G.J., 1983. Effect of genotype, flowering date and environment on oil content and oil quality of wild sunflower seed. Crop Sci. 23, 1063-1068.

Shahidi, F., 1990. Rapeseed and canola: global production and distribution. In: Shahidi, F. (Ed.), Canola and Rapeseed Production, Chemistry, Nutrition and Processing Technology. Van Norstrand Reinhold Publ., NY, pp. 3-13.

Slack, C.R., Rughan, P.G., 1978. Rapid temperature induced changes in the fatty acid composition of certain lipids in developing linseed and soybean cotyledons. Biochem. J. 170, 437-439.

Yaniv, Z., Ranen, C., Levy, A., Palevitch, D., 1989. Effect of temperature on the fatty acid composition and yield of "Evening Primrose" (Oenothera lamarckiana) seeds. J. Exp. Bot. 40, 609-613.

Yaniv, Z., Schafferman, D., Zur, M., 1995. The effect of temperature on oil quality and yield parameters of high- and low-erucic acid Cruciferae seeds (rape and mustard). Ind. Crops Prod. 3, 247-251. 